\title{
Dimensions of Plots Belonging to Out-of-village Owners in the Village of Będziemyśl, Commune of Sędziszów Małopolski
}

\section{Introduction}

The spatial layout of the countryside in south-eastern Poland is the result of socio-economic, historic and demographic processes. The population inhabiting the Podkarpackie voivodship mainly lives in rural areas. It is therefore necessary to make investments in the social and technical infrastructure of the countryside so as to improve the living conditions of the locals.

Plots belonging to individual owners are very often situated within the so-called patchwork layout which means that they are scattered between the plots belonging to other owners. Such plots can be located within the area of the locality in which their owner lives and in this case one can talk about an intra-village patchwork, whereas if the owner lives outside of the area of the village in which he owns lots, one can talk about an inter-village patchworks, also referred to as an external patchwork [4]. The households owning lands in the external patchwork are called "różniczanie" in Polish, meaning out-of-village ownership.

The emergence of an external patchwork is a very negative phenomenon considering that the distance between the plots of a given owner and his or her place of residence increases, which means that the cost of getting to the plots grows as well causing the income and profit of the farmer to dwindle [3].

The process in which a land patchwork comes into being is highly complicated. It has to do with social and economical changes, as well as with demographic development and original settlement. One of its main causes is the fact of succession and inheriting land. As a result of dividing the property, plots were subdivided into smaller areas and passed on to the heirs. The situation of land in relation to the main household centre is an important factor determining the land layout in a given

* Rzeszów School of Engineering and Economics, Chair in Cadastre and Geodetic Design, Rzeszów, Poland

** Poviat Starosty in Ropczyce, Department of Geodesy and Land Management, Poland

*** Lviv National Agrarian University, Department of Land Cadastre, Ukraine 
village. The plots belonging to a particular owner should be placed as close to where he or she lives as possible. This facilitates the land management and drives down the production and transportation costs.

\section{A Description of the Village of Będziemyśl}

The village of Będziemyśl is one of 15 localities situated in the commune of Sędziszów Małopolski in the Ropczyce-Sędziszów poviat. It is located in the central-western part of the Podkarpackie voivodship. From the east it borders the commune of Świlcza and from the south - the commune of Iwierzyce. Its surface equals 524.0 ha which is $3.4 \%$ of the total surface of the commune (Fig. 1).

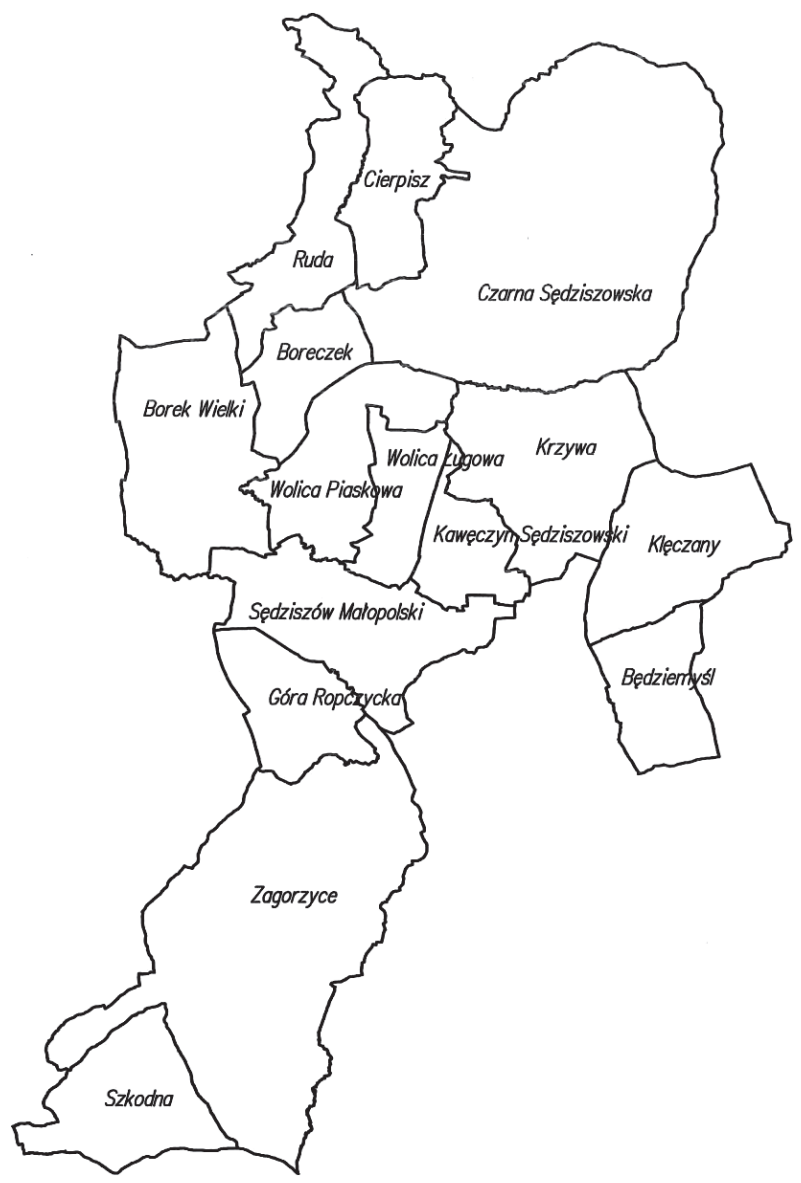

Fig. 1. Spatial layout of the Sędziszów Małopolski commune

Source: own study based on data from the Poviat Centre for Geodetic and Cartographic Documentation in Ropczyce 


\section{The Structure of Land Ownership and Use}

The analysis of land ownership structure shows that plots owned by natural persons (individuals) dominate in the village of Będziemyśl, covering the total of 443.10 ha which equals as much as $84.50 \%$ of the village surface. These are followed by plots belonging to the Treasury (state-owned) except for plots leased out for perpetual usufruct. These plots cover the surface of 44.22 ha which equals $8.43 \%$. The next group consists of plots belonging to the Treasury which are leased out for perpetual usufruct, covering the surface of 14.53 ha which equals $2.77 \%$ of the total village surface. Next, there are plots owned by the commune and unions of communes, except for plots leased out for perpetual usufruct. These cover 13.71 ha which equals $2.62 \%$. They are followed by plots belonging to poviats except for plots leased out for perpetual usufruct, which cover 4.08 ha which is equal to $0.78 \%$ of the total surface. The land owned by churches and religious communities covers the area of 4.02 ha which equals $0.77 \%$ of the surface under investigation. The least sizeable area is the land owned by the co-operative which covers 0.02 ha and has no percentage share in the total surface of the village. The data presented thus far proves how dominant is the share of individual households. It has to do with the structure of land use in farm households.

Individual land ownership has a significant influence on the way land is used in a given village. The structure of land use is an important factor determining the profitability of farming production. As was evident in the analysis of usable land in the village of Będziemyśl, the largest area is covered by cultivated land: 433.25 ha which makes up $82.61 \%$ of the village surface. The largest group is represented by arable land $(53.92 \%)$, followed by permanent pastures $(12.07 \%)$, orchards $(10.23 \%)$, permanent grassland $(3.40 \%)$ and built-up agricultural land $(2.68 \%)$. The smallest area is taken up by ditches $(0.31 \%)$ and land underneath ponds (pond bottoms) which does not constitute any percentage share in the usable land surface. The following group of usable land is: forests along and wooded and bushy lands covering the area of 47.51 ha which makes $9.06 \%$ of the total surface of the village. Wooded and bushy lands cover the area of 37.90 which equals $7.23 \%$, whereas forests cover 9.61 ha which makes 1.83\%. Built-up and urbanized land cover 41.83 ha of the village surface which makes $7.99 \%$ of its total area. The largest share in that land is made up of roads and railway land which together cover the area of 31.08 ha which equals $5.93 \%$, while residential areas take up the surface of 6.37 ha which makes $1.21 \%$. Industrial areas, other built-up and not built-up areas as well as leisure and recreation areas taken together cover the area of 4.38 ha which gives an insignificant percentage share of only $0.85 \%$. Wastelands cover the area of 1.73 ha which makes $0.33 \%$. The smallest percentage share is represented by lands under water. The lands under standing water take up solely 0.06 ha which is equal to $0.01 \%$. 


\section{The Structure of Land Fragmentation}

The original settlement layout underwent substantial transformation due to human activity. The evolution which took place in the spatial layout of land led to a significant fragmentation and scattering of cadastral parcels which make up farm households. Plots with a small surface as well as those which are elongated or have diversified shapes are often not suited for carrying out field work in agriculture. Despite the intense fragmentation of land, no direct access roads have been built. What follows is that a number of plots are not connected to the household of residence [5].

The fragmentation of cadastral parcels has a negative influence on agricultural production by driving production costs and thwarting the development of farming. The total surface of the village in the area under investigation (Tab. 1) equals 524.38 ha and it is divided into 1505 cadastral plots. The plots under analysis belong to individuals and they are 1340 plots with the total surface of 439.55 ha.

Table 1. The structure of land fragmentation in the village of Będziemyśl

\begin{tabular}{|c|c|c|c|c|c|c|}
\hline No. & Range & $\begin{array}{c}\text { Number of } \\
\text { plots }\end{array}$ & $\begin{array}{c}\text { Number of } \\
\text { plots [\%] }\end{array}$ & $\begin{array}{c}\text { Surface } \\
\text { together } \\
\text { [ha] }\end{array}$ & $\begin{array}{c}\text { Share in the } \\
\text { surface [\%] }\end{array}$ & $\begin{array}{c}\text { Average } \\
\text { surface [ha] }\end{array}$ \\
\hline \hline 1 & $0.00-0.10$ & 410 & 30.60 & 19.41 & 4.42 & 0.05 \\
\hline 2 & $0.11-0.20$ & 327 & 24.40 & 46.23 & 10.52 & 0.14 \\
\hline 3 & $0.21-0.30$ & 190 & 14.18 & 46.26 & 10.52 & 0.24 \\
\hline 4 & $0.31-0.60$ & 253 & 18.88 & 106.35 & 24.20 & 0.42 \\
\hline 5 & $0.61-1.00$ & 109 & 8.13 & 80.62 & 18.34 & 0.74 \\
\hline 6 & $\geq 1.01$ & 51 & 3.81 & 140.68 & 32.00 & 2.76 \\
\hline \multicolumn{2}{|c|}{ Total: } & 1340 & 100.00 & 439.55 & 100.00 & - \\
\hline
\end{tabular}

Source: own study based on data from the Land and Property Register

As transpires from the research (Tab. 1), the highest number of plots falls into the range up to 0.10 ha which makes as much as 30.60\% of all plots in Będziemyśl. The next group consists of plots between 0.11 and 0.20 ha which equal $24.40 \%$. The plots sized from 0.21 to 0.30 ha make $14.18 \%$ and there are 190 of them. The quoted size ranges constitute only a small percentage share of the total area of the village under investigation. The number of cadastral plots sized in the range $0.31-0.60$ ha is 1253 and that equals $18.88 \%$. The following size range for cadastral plots, from 0.61 to 1.00 ha makes $8.13 \%$. Plots exceeding the size of 1 hectare constitute a small percentage share in the total number of plots. When it comes to their surface, they take up the area of over 140 ha which equals $32 \%$ of the total area of the village. 
As is evident from the calculations, the fragmentation of plots in the investigated area is fairly significant. This state of things is highly disadvantageous for agriculture due to the high degree of fragmentation of cadastral plots leading to the emergence of an internal plot patchwork. In accordance with the Act of $21^{\text {st }}$ August 1997 concerning real property management plots smaller than 0.30 ha may not be further divided.

\section{The External Plot Patchwork of the Village of Będziemyśl}

The emergence of plot patchwork in Poland and other countries alike is the result of decades-long transformations of social, legal and economic nature. The term was coined in 1907 by Koncent-Zieliński, who wrote: "a patchwork of plots is how one refers to such a land layout belonging to a given village in which the plots of particular owners are not located in one unified piece by the house, but are fragmented into a larger number of plots, usually narrow and long, scattered over a vast area and interspersed with the plots of other owners" [2]. Among other authors who defined the phenomenon in question in a similar way, one can name Radwan [8] and Tkocz [9]. The concept of a patchwork was described in a broader sense by Hopfer, who also wrote about the patchwork of usable land, cultivation and soil valuation classes [1]. Land patchworks are classified according to administrative divisions: internal patchworks (within a village) and external ones (inter-village, inter-commune, inter-voivodship, international) [7].

In the countryside in the south of Poland one can recognise the presence of the external kind of plot patchwork. The connections between particular localities with relation to services, work or culture influences to a large degree the presence of the external plot patchwork. The mutual interaction of localities varies and one can distinguish stronger and weaker external and internal connections within the spatial layout of the analysed area [6].

The village of Będziemyśl covers the area of 524.38 ha and is divided into 1505 cadastral parcels. As can be inferred from Table 2, the land belonging to out-of-village owners takes up the area of 139.87 ha which makes $26.67 \%$ of the total surface of the village. This land is divided into 301 plots which makes a $20.01 \%$ share. 50 plot owners from the commune of Sędziszów Małopolski do not reside in Będziemyśl. 88 cadastral plots are in their possession, which makes $14.32 \%$. The largest number of plots are owned by residents from the village of Klęczany. They have 38 plots with the total area of 15.33 ha. In terms of surface, the largest group is made up of land belonging to owners from Sędziszów Małopolski; their land covers 53.47 ha and is divided into 25 plots belonging to 17 owners. The remaining localities which belong to the commune of Sędziszów Małopolski are in the possession of between 1 and 9 plots with surfaces ranging from 0.16 to $2.23 \mathrm{ha}$. The plots belonging to 30 owners from the commune of Iwierzyce take up the area of 11.95 ha and they make a total of 46 plots. 
Table 2. Dimensions of plots belonging to out-of-village owners

\begin{tabular}{|c|c|c|c|c|c|c|c|}
\hline $\begin{array}{l}\text { Out-of-village } \\
\text { owners from the } \\
\text { commune }\end{array}$ & No. & Locality & $\begin{array}{c}\text { Num- } \\
\text { ber of } \\
\text { plot } \\
\text { owners }\end{array}$ & $\begin{array}{l}\text { Num- } \\
\text { ber of } \\
\text { plots }\end{array}$ & $\begin{array}{l}\text { Number } \\
\text { of plots in } \\
\text { the total } \\
\text { number of } \\
\text { plots in the } \\
\text { village [\%] }\end{array}$ & $\begin{array}{l}\text { Surface } \\
\text { of plots }\end{array}$ & $\begin{array}{c}\text { Share of the } \\
\text { surface of the } \\
\text { plots in the } \\
\text { total surface } \\
\text { of the village } \\
\text { [\%] }\end{array}$ \\
\hline \multirow{10}{*}{$\begin{array}{l}\text { of Sędziszów } \\
\text { Małopolski }\end{array}$} & 1 & $\begin{array}{l}\text { Czarna } \\
\text { Sędziszowska }\end{array}$ & 1 & 3 & 0.20 & 1.13 & 0.22 \\
\hline & 2 & Borek Mały & 1 & 2 & 0.13 & 0.49 & 0.09 \\
\hline & 3 & Góra Ropczycka & 2 & 2 & 0.13 & 0.22 & 0.04 \\
\hline & 4 & Klęczany & 17 & 38 & 2.52 & 15.33 & 2.92 \\
\hline & 5 & Krzywa & 4 & 5 & 0.33 & 1.62 & 0.31 \\
\hline & 6 & Kawęczyn Sędz. & 5 & 9 & 0.60 & 2.23 & 0.43 \\
\hline & 7 & Sędziszów Młp. & 17 & 25 & 1.66 & 53.47 & 10.20 \\
\hline & 8 & Wolica Ługowa & 2 & 3 & 0.20 & 0.16 & 0.03 \\
\hline & 9 & Zagorzyce & 1 & 1 & 0.07 & 0.42 & 0.08 \\
\hline & \multicolumn{2}{|r|}{ Total: } & 50 & 88 & 5.84 & 75.07 & 14.32 \\
\hline \multirow{4}{*}{ of Iwierzyce } & 10 & Bystrzyca & 1 & 2 & 0.13 & 0.50 & 0.09 \\
\hline & 11 & Olchowa & 12 & 12 & 0.80 & 3.29 & 0.63 \\
\hline & 12 & Nockowa & 17 & 32 & 2.13 & 8.16 & 1.56 \\
\hline & \multicolumn{2}{|r|}{ Total: } & 30 & 46 & 3.06 & 11.95 & 2.28 \\
\hline \multirow{6}{*}{ of Świlcza } & 13 & Dąbrowa & 16 & 35 & 2.32 & 12.37 & 2.36 \\
\hline & 14 & $\begin{array}{l}\text { Błędowa } \\
\text { Zgłobieńska }\end{array}$ & 1 & 3 & 0.20 & 0.25 & 0.05 \\
\hline & 15 & Bratkowice & 1 & 4 & 0.27 & 0.36 & 0.07 \\
\hline & 16 & Mrowla & 3 & 3 & 0.20 & 2.78 & 0.53 \\
\hline & 17 & Trzciana & 5 & 6 & 0.40 & 1.05 & 0.2 \\
\hline & \multicolumn{2}{|r|}{ Total: } & 26 & 51 & 3.39 & 16.81 & 3.21 \\
\hline \multirow{3}{*}{$\begin{array}{l}\text { of Ropczyce- } \\
\text {-Sędziszów }\end{array}$} & 18 & Kamionka & 1 & 1 & 0.07 & 0.48 & 0.09 \\
\hline & 19 & Ropczyce & 5 & 6 & 0.40 & 2.42 & 0.46 \\
\hline & \multicolumn{2}{|r|}{ Total: } & 6 & 7 & 0.47 & 2.90 & 0.55 \\
\hline \multirow{3}{*}{$\begin{array}{l}\text { from the } \\
\text { voivodship }\end{array}$} & 20 & Rzeszów & 40 & 61 & 4.05 & 23.02 & 4.39 \\
\hline & 21 & Others & 19 & 40 & 2.66 & 7.72 & 1.47 \\
\hline & \multicolumn{2}{|r|}{ Total: } & 59 & 101 & 6.71 & 30.74 & 5.86 \\
\hline- & 22 & $\begin{array}{l}\text { Out-of-village } \\
\text { owners from Poland }\end{array}$ & 6 & 7 & 0.47 & 2.06 & 0.39 \\
\hline- & 23 & $\begin{array}{l}\text { Out-of-village } \\
\text { owners from abroad }\end{array}$ & 1 & 1 & 0.07 & 0.34 & 0.06 \\
\hline & & Total: & 172 & 301 & 20.01 & 139.87 & 26.67 \\
\hline
\end{tabular}

Source: own study based on data from the Land and Property Register 
The largest amount of land remains in the hands of the owners from Nockowa, with the total area of 8.16 ha and 32 cadastral plots between 17 owners. A significant number of out-of-village land owners live in the locality of Olchowa - they are 12 owners holding 12 plots, making up the total of 3.29 ha. One owner from the village of Bystrzyca has in his possession 2 plots with the surface of 0.5 ha. 26 out-of-village owners from the commune of Świlcza together hold 51 plots which cover the area of 16.81 which makes $3.21 \%$ of the total area of the village. It is the owners from Dąbrowa to whom the most land belongs. They own 35 plots with the joint surface of $12.37 \mathrm{ha}$. The remaining localities are in possession of between 0.25 to 2.78 ha of the land in Będziemyśl, owning between 3 and 6 plots.

Land owners from the poviat of Ropczyce-Sędziszów have 7 plots, 6 out of which belong to residents of Ropczyce, making up the total surface of $2.42 \mathrm{ha}$. One plot remains in the hands of a resident from Kamionka, and it has 0.48 ha. The out-of-village owners living in the Podkarpackie voivodship have 101 plots taking up the area of 30.74 ha, which makes $6.71 \%$ of the total surface of land in the village. The city of Rzeszów has a strong influence on Będziemyśl. 40 owners living in Rzeszów have 61 plots with the joint surface of 23.02 ha. Other localities take up the area of 7.72 ha, divided into 40 plots. Land belonging to out-of-village owners who live in Poland consists of 7 plots in the hands of 6 people, covering the area of 2.06 ha. Finally, one owner who lives abroad has one plot with a surface of 0.34 ha.

\section{Summary and Conclusions}

Having completed the analysis of the area under investigation, one can list the following conclusions:

1. The dominant group in terms of land ownership consists of individuals who own $84.5 \%$ of the area of the studied village.

2. The dominant group in the village of Będziemyśl consists of cultivated land which covers $82.6 \%$ of the village area.

3. The analysis of individual land fragmentation has shown that: the plots sized up to 0.10 ha make up $30.60 \%$ of the total number of plots whereas those sized from 0.11 to 0.20 ha make up $24.40 \%$ of the total number.

4. The analysis of the external plot patchwork has shown that as much as $26.67 \%$ of the total area of the village is taken up by land belonging to out-of-village owners.

The conducted research evidenced the land in the village of Będziemyśl to be defective due to its significant fragmentation, the scattering of plots and the presence of an external plot patchwork. The indicated factors inhibit the development of and investment into agriculture in the investigated area. The conducted analysis has shown how strong the influence of neighbouring localities is on the studied village. 
This is a chance to reduce the problem of plot patchwork through the consolidation and exchange of plots. Other places which exert a major influence on the village are larger towns, mainly Rzeszów and Sędziszów Małopolski. It is caused by the favourable location of the village and the possibility of buying cadastral plots for future single-family residential housing.

\section{References}

[1] Hopfer A.: Niektóre problemy oceny szachownicy gruntów rolnych. Problemy urządzania obszarów wiejskich w pótnocnych rejonach Polski. SGP NOT, Olsztyn 1978.

[2] Koncent-Zieliński W.: Jak usuwać szachownicę i przeprowadzać kolonizacje gruntów. Warszawa 1907.

[3] Leń P.: Rozmiary gruntów różniczan i możliwości ich likwidacji (na przykładzie wsi w powiecie Brzozów, województwo Podkarpackie. XVII Ogólnopolska Konferencja "Nowe tendencje w teorii i praktyce urządzania obszarów wiejskich" "Rozwój obszarów wiejskich - stan obecny i perspektywy", Puławy 2009.

[4] Leń P.: Prawidłowości w rozmiarze występowania gruntów różniczan zamiejscowych na przykładzie wsi w powiecie Brzozów. Infrastruktura i Ekologia Terenów Wiejskich, nr 1/II, 2012, pp. 137-145.

[5] Noga K.: Analiza międzywioskowej szachownicy gruntów na przykładzie wsi położonych w górnym dorzeczu Soły. ZN AR w Krakowie nr 133, Sesja Naukowa 7, Kraków 1977.

[6] Noga K.: Metodyka programowania i realizacji prac scalenia i wymiany gruntów w ujęciu kompleksowym. Szkoła Wiedzy o Terenie, Akademia Rolnicza, Kraków 2001.

[7] Rabczuk I.: Problem różniczan w pow. proszowickim, woj. krakowskie. [in:] Aktualne zagadnienia geodezji urządzeniowo-rolnej, Wydawnictwo Czasopism Technicznych NOT, Warszawa 1968, pp. 65-70.

[8] Radwan J.: Zagadnienie scalania gospodarstw wiejskich w Polsce. Zeszyt Specjalny Czasopisma "Rolnictwo", z. 201, Towarzystwo Oświaty Rolniczej, Warszawa 1938.

[9] Tkocz J:. Rozłogi województwa opolskiego. Instytut Śląski, Wrocław - Opole 1971. 